\title{
A Relationship Between Contraception Service Sources And Modern Contraception Methods Used By Couples Of Childbearing Age In Indonesia
}

\author{
Dyah Pradnya Paramita ${ }^{1}$, Ratih Devi Alfiana, Lia Dian Ayuningrum, Fatimatasari \\ ${ }^{1}$ Departement Of Midwifery, Faculty of Sciences, Alma Ata University \\ Jalan Brawijaya No. 99 Tamantirto, Bantul, Yogyakarta \\ Email: dyahpradnya.paramita@almaata.ac.id
}

\begin{abstract}
Abstrak
Peningkatan jumlah penduduk merupakan masalah besar bagi negara. Untuk menangani permasalahan tersebut, maka jumlah pasangan usia subur (PUS) yang menggunakan kontrasepsi harus ditingkatkan. Menurut Survei Demografi Kesehatan Indonesia (SDKI) tahun 2017, tingkat penggunaan alat kontrasepsi di Indonesia hanya 57\%. Untuk meningkatkan jumlah penggunaan alat kontrasepsi tersebut, perlu adanya peran dari fasilitas kesehatan yang tidak hanya sebagai penyedia alat/cara kontrasepsi tetapi juga sebagai pemberi layanan promotif dan preventif, sehingga PUS dapat secara rasional memilih alat kontrasepsi yang akan digunakan sesuai kebutuhannya. Tujuan penelitian ini untuk mengetahui hubungan sumber pelayanan kontrasepsi dengan metode kontrasepsi modern yang digunakan oleh PUS. Penelitian ini merupakan penelitian data sekunder dari Survei Kinerja dan Akuntabilitas Program Kependudukan, Keluarga Berencana dan Pembangunan Keluarga (SKAP-KKBPK) 2018 dengan desain penelitian crosssesctional dan analisis bivariate Uji chi-square. Populasi penelitian ini adalah seluruh pasangan usia subur di Indonesia yang menjadi responden SKAP-KKBPK 2018 yaitu sebanyak 60.599 pasangan, sedangkan samplenya yaitu seluruh PUS yang menggunakan alat kontrasepsi modern. Sample berjumlah 26.776 PUS ditentukan dengan teknik stratified multistage sampling. Dari hasil penelitian diketahui bahwa sebanyak 76,9\% PUS memilih menggunakan kontrasepsi non MKJP dan 76,51\% memilih berkunjung ke sumber pelayanan kontrasepsi milik swasta untuk mendapatkan alat kontrasepsi tersebut. PUS pengguna kontrasepsi non MKJP lebih banyak yang berkunjung ke sumber pelayanan kontrasepsi milik swasta (85,9\%) sedangkan PUS pengguna kontrasepsi MKJP lebih banyak yang berkunjung ke sumber pelayanan kontrasepsi milik pemerintah (52,6\%). Kesimpulan dari penelitian ini adalah adanya hubungan antara sumber pelayanan kontrasepsi dengan metode kontrasepsi modern yang digunakan oleh PUS. Oleh karenanya sumber pelayanan kontrasepsi perlu memberikan pelayanan yang berkualitas agar dapat mendorong PUS untuk memilih alat kontrasepsi yang akan digunakan secara rasional dan sesuai kebutuhannya.
\end{abstract}

Kata Kunci: metode kontraepsi modern; sumber pelayanan kontrasepsi; pasangan usia subur 
research aimed to discover the relationship between contraceptive service sources and the modern contraceptive method used by couples of childbearing age. This research used the secondary data from the 2018 Program Performance and Accountability Survey of Population, Family Planning, and Family Development (abbreviated SKAP-KKBPK in Indonesia), using the cross-sectional research design and the Chi-square bivariate analysis. The population used in this research was all couples of childbearing age in Indonesia who becomes responden in SKAP-KKBPK, which were 60.599 couples, and the samples were all couples of childbearing age who used modern contraception, which were 26,776 couples. The research known that as much as $76,9 \%$ couple of childbearing chose to use short-term contraceptive methods and $76,51 \%$ choose visit to a source of private service contraceptive to get those contraceptives. Couples of childbearing age who use short-term contraceptive visit to private service contraceptive (85.9\%) and couples of childbearing age who use long term contraceptive visit to government service contraceptive $(52.6 \%)$. The conclusion of this research is the relationship between source service contraception with modern contraception method used. The source service contraceptive must to offer the quality service to encourage. So that couples of childbearing age can rationally choose the contraception to be used as needed.

Keywords: modern contraception methods; contraception service source; couple of childbearing age

Article info:

Article submitted on August 10, 2020

Articles revised on September 25, 2020

Articles received on October 15, 2020

DOI: http://dx.doi.org/10.21927/jnki.2020.8(3).185-193

\section{INTRODUCTION}

As seen from the Total Fertility Rate (TFR), the population projection in Indonesia in 2015 to 2045 starts to stagnate in 2020 at 2.1. This will make Indonesia the $4^{\text {th }}$ country with the lowest population growth in the ASEAN level (1). To realize this projection, the Government continues to strive in order to reduce the population growth rate by implementing a family planning program, covered by the National Family Planning Coordinating Board (abbreviated $B K K B N$ in Indonesia). The family planning program is recognized as one of the programs capable of reducing the fertility rate through Early Marriage Postponement and Contraceptive Use (2) Pekanbaru City and has a higher population growth than the other regencies / cities in Riau Province. The purpose of this study is to see how much influence family planning programs in reducing the rate of population growth in the city of Pekanbaru. Methods of data analysis used in this study is descriptive method with qualitative approach. The data analysis technique used in this study is the analysis of qualitative data that outlines and interpret the data obtained in the field of the key informants (key informants.

The number of contraceptive use among women aged 15 to 49 years old, married or living together, has reached $57 \%$ according to the 2017 SDKI. And based on the survey, the most widely used contraceptive method was the injection, which was $29 \%$, followed by the $12 \%$ which was the pill, $5 \%$ which were the implant and the intra-uterine devices (IUD), 4\% which was MOW, and $3 \%$ which was the condom. It was also known that young women tended to use the short-term contraceptive methods (nonMKJP) such as the injection, pills, and also the long-term contraceptive methods (MKJP) such as the implant; while older women tended to use 
long-term contraceptive methods such as IUD and sterilization (3). The use of those short-term contraceptive methods caused the continuity rate of contraceptive use to tend to decrease, which had an impact on the fertility rate growth.

Choosing the right contraceptive method is an important factor for the family planning program. Based on the effectiveness, contraceptive methods are categorized into two: the injection, pills, and condoms are categorized as the nonMKJP; while the IUD, implant, MOW, and MOP are categorized as the MKJP (4).

The factors that influence the behavior of couples of childbearing age in choosing the contraceptive method cannot be separated from the influence of the behavioral factors that each individual has. Related to the theory of behavior, how the behavior is formed is influenced by three factors, namely predisposing, enabling, and reinforcing factors. Predisposing factors can be seen from age, education, knowledge, attitude, parity, and health history; while enabling factors include family planning services (rooms, tools, and transportation); and reinforcing factors in this case are the supports from the husbands and the family planning service officers (5). In one research, it was found that only $40 \%$ of family planning acceptors had knowledge of the correct contraceptive method. Therefore, it is necessary to improve the quality of the family planning program, so that couples of childbearing agehave knowledge of the correct contraceptive method (6).

One of the functions of a health facility, apart from being a provider of contraceptive methods, is to increase the couples of childbearing age knowledge about the correct contraceptive method. To do so, health facilities need to be equipped with decision-making tools and provide information about family planning, so as to increase the patients' involvement in the decision-making process in determining the right choice of contraceptive method according to their needs (7).

To increase the number of couples of childbearing age to use contraception, the government has been facilitating access to contraceptive services and ensuring the contraception availability. The public can get contraception either from the government or private sources of contraceptive services. The examples of the government sources of contraceptive services are Public Health Centers, family planning clinics, and government hospitals; and the examples of the private contraceptive service sources are private doctors/midwives, family planning clinics/ private hospitals, pharmacies, drug stores, and others (8). Based on the 2017 IDHS, 48\% of couples of childbearing age mostly obtain contraception from the private family planning services, while $34 \%$ of couples of childbearing age obtain contraception from the state-owned (government) family planning services (3). The quality of services is one factor that goes to ground the community in determining the health facilities force. In previous studies, community satisfaction levels towards private health facilities is higher than goverment health facilities. All of the responden in that research feel satisfied with private health service. That satisfaction is aimed in dimensions of quality, physical appearance, responsiveness and empathy (9).

Therefore, researchers would like to analyze the relationship between contraceptive service sources and modern contraceptive methods that are used by the couples of childbearing age in Indonesia.

\section{MATERIALS AND METHODS}

This research is a secondary data research from the SKAP-KKBK of 2018, where the sample is obtained by the stratified multistage sampling method. 


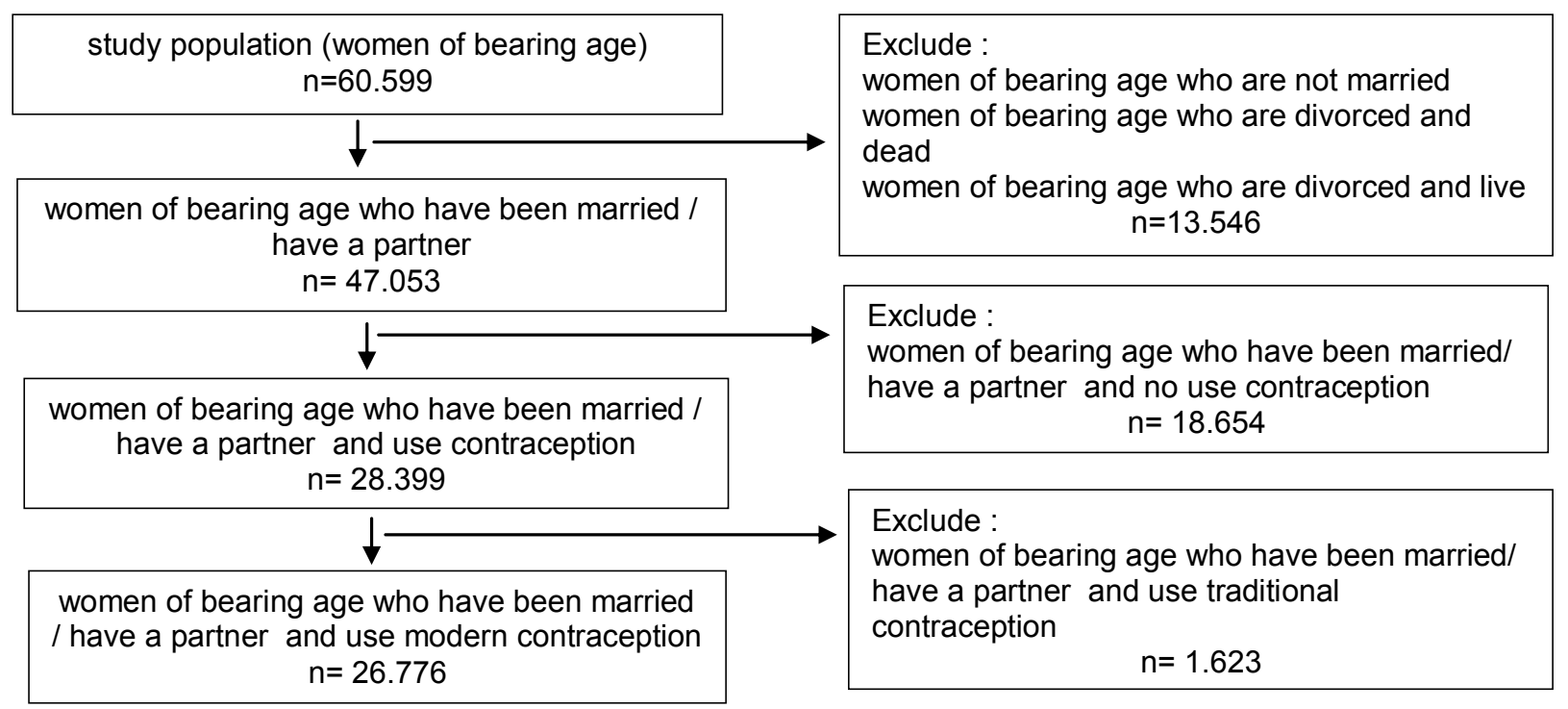

This research using the cross-sectional design. The data were analyzed in univariate and bivariate ways. For the bivariate analysis, the statistical test used was the Chi-square.

\section{RESULTS AND DISCUSSION}

\section{Overview of Contraception Methods Usage}

Based on table 1, it is known that the modern contraception method most preferred by the couples of childbearing age in Indonesia in 2018 is the shortterm contraception method. Monthly injectables contraceptives is one of the contraception included in the category of short-term contraceptive methods (non-MKJP). Most or as many as 12,443 (46.5\%) PUS choose this contraception method. Meanwhile, the contraception included in the long-term contraception method most used by the reproductive couples is the implants, which is $2182(8.1 \%)$.

\section{Overview of Visited Contraception Service Sources to Get Contraception}

Table 2 shows that the needs for contraception services can be obtained from the government and the private sector. In order to obtain the desired contraception devices, more couples of childbearing age visit the private contraception service sources. Of the

Table 1. Respondents Distribution Based on the Used Modern Contraception Methods

\begin{tabular}{lrr}
\hline \multicolumn{1}{c}{ Contraception Method } & N & \% \\
\hline MKJP & & \\
Female sterilization/tubectomy & 1568 & 5.9 \\
Male sterilization/vasectomy & 69 & .3 \\
KB Implant & 2373 & 8.9 \\
IUD/spiral & 2181 & 8.1 \\
Non-MKJP & & \\
Monthly injectables contraceptives & 12443 & 46.5 \\
combined injectable contraceptives & 1903 & 7.1 \\
Pill & 5432 & 20.3 \\
Emergency contraception & 14 & .1 \\
Male condom & 787 & 2.9 \\
Female condom & 6 & .0 \\
\hline Total & 26776 & 100.0 \\
\hline
\end{tabular}

various sources of contraception services, both government and private, the private midwife practice is the most widely accessed source of contraception services by the couple of bearing age, which is $7,568(28.3 \%)$.

Based on Table 3, it can be concluded that the variables of contraception service sources and the contraception methods chosen by couples of childbearing age are interrelated. These results are shown from the value ( $p$-value) which is less than 0.05 . The contraception method most preferred by the couples of childbearing age is the non-MKJP, which is $20,584(76.9 \%)$. couples of childbearing age who visit the private contraception services 
Table 2. Respondents Distribution Based on the Visited Contraception Service Sources to Get Contraception Devices

\begin{tabular}{lcc}
\hline \multicolumn{1}{c}{ KB Service Sources } & $\mathrm{N}$ & $\%$ \\
\hline Government & & \\
Government hospital & 1294 & 4.8 \\
Public Health Center & 3447 & 12.9 \\
Subsidiary Public Health Center & 350 & 1.3 \\
KB Field Extension & 87 & .3 \\
Mobile KB Unit & 178 & .7 \\
Village Health Center & 227 & .8 \\
Village Maternity Cottage & 546 & 2.0 \\
KB Cadre & 159 & .6 \\
Integrated Health Center & 270 & 1.0 \\
Private & & \\
Private hospital & 888 & 3.3 \\
Maternity hospital & 248 & .9 \\
Maternity house & 178 & .7 \\
Private clinic & 678 & 2.5 \\
General medical doctor practice & 203 & .8 \\
Obstetrician practice & 168 & .6 \\
Private midwife practice & 7568 & 28.3 \\
Nurse practice & 244 & .9 \\
Village midwife & 7116 & 26.6 \\
Pharmacy/drugs store & 2136 & 8.0 \\
Friends/relatives & 209 & .8 \\
Store & 412 & 1.5 \\
Others & 165 & .6 \\
Do not know/not remember & 3 & .0 \\
\hline Total & 26776 & 100.0 \\
\hline
\end{tabular}

preferred the non-MJKP contraception methods, while couples of childbearing age who visit the government contraception services are more likely to use MKJP.

\section{Relationship between Contraception Service Sources and Contraception Methods Used by Couples of Childbearing Age}

\section{Discussion}

Contraception is an attempt to prevent pregnancy. This attempt can be temporary and permanent (10). Contraception is divided into hormonal and non-hormonal methods, simple method, and steady method. In this research, the most widely used contraception method is Monthly injectables contraceptives. The results of the study are consistent with Pratiwi ED and Sariyati research. Injectables contraceptives is most commonly used by the couples of childbearing agein Sedayu Bantul (11). Monthly of injectables contraceptives is a type of hormonal contraception. This contraception contains the hormone norethindrone enanthate (norethisterone enanthate or NETE). Monthly injectables contraceptives has a very low failure rate, which is less than 0.5 per 100 women per year (10). The high number of injectable contraception usage in this research is also supported by previous research which states that injectable contraception is the tool most widely used by reproductive couples (12).

One of the factors that influence the use of contraception is socioeconomic status. The higher the economic status of reproductive couples, the easier it is to get contraception devices (12). In one research, it was stated that there was a significant relationship between the KB acceptors' income and the choice of injection contraception. Apart from being more effective, the price of injection contraception is more affordable then the IUD method or other methods. Although the price of injection contraception is slightly more expensive than the price of contraception pills, its use is more practical, and can avoid about being forgotten to consume birth control pills (13).

Table 3. Relationship between Contraception Service Sources and Contraception Methods Used by Couples of Childbearing Age

\begin{tabular}{|c|c|c|c|c|c|c|c|}
\hline \multirow{3}{*}{$\begin{array}{c}\text { Contraception } \\
\text { Service } \\
\text { Source }\end{array}$} & \multicolumn{6}{|c|}{ Contraception Method } & \multirow{3}{*}{ p-value } \\
\hline & \multicolumn{2}{|c|}{ MKJP } & \multicolumn{2}{|c|}{ Non-MKJP } & \multicolumn{2}{|c|}{ Total } & \\
\hline & $\mathbf{n}$ & $\%$ & $n$ & $\%$ & $\mathbf{n}$ & $\%$ & \\
\hline Government & 3307 & 52.6 & 2928 & 47.4 & 6289 & 100.0 & 0.000 \\
\hline Private & 2885 & 14.1 & 17602 & 85.9 & 20487 & 100.0 & \\
\hline Total & 6192 & 23.1 & 20584 & 76.9 & 26776 & 100.0 & \\
\hline
\end{tabular}


Apart from its effectiveness, cost, and ease of use, monthly injectables contraception is widely chosen for its faster return to fertility, compared to the combined injectable contraception. This is in line with previous research which states that the average time to return to pregnancy, in the respondents using the monthly injectables contraception, is faster those who use the combined injectable contraception with an average time to return to pregnancy with monthly injectables contraception, namely 4.12 months; whereas in combined injectable, the average time to return to pregnancy is 8.63 months (14).

The results of this study also indicate that in order to obtain the desired contraception methods, the number of couple of childbearing age visiting private contraception service sources, especially the private midwife practices, is more than the number of couple of childbearing visiting other contraception service sources. This condition is in accordance with the results of Health Facilities Research in 2011 which stated that the access of couple of childbearing age to midwives dominated the access to the fulfillment of contraception needs in Indonesia (15). The results of other studies also indicate that most mothers, either living in urban or rural areas, choose their contraception services in the private midwife practice. The domination of access to the $\mathrm{KB}$ services in private midwife practices is due to the fact that the private midwife practices are easily found by the local community, and that the female service providers are psychosocially believed to create a sense of comfort for the mothers (16).

In this research, the large number of respondents who access the private contraception service sources is also because of a substantial difference assumption in the quality, between the private and the government contraception services. A literature study in America on the quality of family planning services, which is mostly based on the survey of client perspective, shows that the quality of service varies depending on the characteristics of the facility, provider, client, and consultation. Generally the quality of service is worse in the government sector than in the private sector. Two provider characteristics are found to be related to the service quality, namely the gender and the provider type. By the clients, female providers are considered to provide higher quality services than male providers, and the majority of clients assume that other types of health providers, other than medical doctors (midwives-nurses), provide higher quality services (17).

The difference in quality between the contraception service sources is also shown in a study in Kenya, that the private sector shows more readiness to provide services and pays greater attention to the clients' needs, so that the clients are more satisfied after receiving services in the private sector (18). The providers in the private sector demonstrate interpersonal relationships during the service delivery process of higher quality than the government, however, not of higher technical quality. In other research, it is also stated that the satisfaction of $\mathrm{KB}$ services is higher in the private sector compared to the government sector, due to the shorter waiting time and rarely runs out of supplies of KB tools and pills (19).

The bivariate analysis results in this research indicate a relationship between the contraception service sources and the contraception methods chosen by the Couples of Childbearing Age. Most of PUS who visit the government contraception service sources use the long-term contraceptive method (MKJP). Meanwhile, PUS who visit the private contraception service sources mostly use the short-term/ non-MKJP contraception methods. This result is in line with the research results by Triyanto and Indriani which states that the Public Health Center, as one source of the government contraception services, is related to the use of IUD. IUD can be obtained free of charge at a Public Health Center since the family 
planning service financing is guaranteed by the National Health Insurance (20). This result is also in line with the research by Nasution and Wahyuni which states that the sources of family planning services influence the use of MKJP for PUS (21).

The lack of MKJP usage in the private institutions is possibly due to the lack of trained health workers, lack of contraception availability, lack of income in the future (since MKJP has a longer protection period), and/or unwillingness to discuss with women about contraception methods thoroughly, as well as the preferences that can be chosen for the women. This is certainly inversely proportional to the government agencies which, in fact, have a wider network and a more diverse cross-sector, such as the free health insurance, the gradual referral system, a variety of training for health workers, and there is more than the private agencies. Thus, it is easier for the women, who get their KB service sources in the government agencies, to access MKJP than the women who get their KB service sources in the private agencies (22).

The high use of non-MKJP contraceptive methods among acceptors visiting private contraceptive service sources, especially private practice midwives as in the results of this study is also due to government policies regulating the authority of private practice midwives in providing contraceptive services. In the Regulation of the Minister of Health of the Republic of Indonesia No. 28 of 2017 concerning Permits and Implementation of Midwife Practices, that midwives are authorized to provide oral contraceptives, condoms, and injections (23). Where contraception is non MKJP contraception. Meanwhile, according to research by Pratiwi $\mathrm{NL}$, Basuki $\mathrm{H}$ in 2014 states that access to family planning services is dominated by private practice midwives (16).

From Aprelia's research, community are satisfied with family planning services that given from midwife. Midwives provide the services quickly, the price of affordable and according to community needs. Midwives have good skill, responsible, keep the privacy of patients, create safety and comfortable during services through the kindness and courtesy while communicating (24).

The high number of couple of childbearing age who visit to midwife also based on midwife provide family planning service start from post partum periode. In research conducted by Pratiwi that postpartum health care is relationed with the use of Contraceptive After Childbirth. Women who get postpartum health care will be more use Contraceptive After Childbirth. Midwifery of care is the comprehensive care that given since the preconception periode to klimakterium periode. So midwife have more opportunity to give information about family planning for couple of childbearing age (25). Midwives give information of family planning for couple of childbearing age with counseling method. This activity is very important to help patients in taking the right decisions about contraceptives. From Aryani's research, midwife have good technique of counseling. When counseling midwives have provided information as required, offer the opportunity for client to express his feelings and support providing (26).

Many couple of childbearing age in Indonesia who choose to get family planning services in the private contraceptive services can be implies that couple of childbearing age preferring to use independently contraception. In Sariyari's research, couple of childbearing age choosing independently contraception because they uncertainty with government services, more easily access and as well as time more flexible (27).

This study has limitations, namely that it cannot explain more deeply the reasons behind the research findings, such as the reason why PUS prefers to use non-MKJP contraceptives in private contraceptive services. 


\section{CONCLUSION AND RECOMMENDATION}

The majority of couple in the childbearing age in Indonesia used short term contraceptive method. The largest proportion for long term contraceptive method that was used by couple in the childbearing age in Indonesia was implant. Meanwhile, the largest proportion for short term contraceptive method that was used by couple in the childbearing age in Indonesia was monthly contraceptive injection. The results of this study showed that the source of contraceptive services were associated with the use of contraceptive methods. Most of couple in the childbearing age who visited government contraceptive services used long term contraceptive method, while the majority of them who visited private contraceptive services used the short term contraceptive method.

Therefore, there is a need for further studies on the effect of policy changes that limit the authority of midwives in contraceptive services on the reduction of long term contraceptive uptake. In addition, there is a need for a qualitative study to unveil the reasons why the majority of couple in the childbearing age in Indonesia does not choose long term contraceptive method.

\section{REFERENCES}

1. BPS Statistics Indonesia. Proyeksi Penduduk Indonesia 2015-2045 Hasil SUPAS 2015. Jakarta; 2018.

2. Pasrah S.D R, Putro T, Indrawati T. Efektivitas Program Keluarga Berencana dalam Menekan Laju Pertumbuhan Penduduk di Kota Pekanbaru. J Online Mhs Fak Ekon Univ Riau. 2014;1(2):1-15.

3. Badan Kependudukan dan Keluarga Berencana Nasional, BPS Statistics Indonesia, Indonesia KKR. Survei Demografi dan Kesehatan Indonesia 2017. 2018.

4. Manuaba IBG. IImu Kebidanan, Penyakit Kandungan dan Keluarga Berencana. Jakarta: EGC; 2010.
5. Notoadmodjo. Promosi Kesehatan dan IImu Perilaku. 1st ed. Jakarta: Rineka Cipta; 2007.

6. Topsever P, Filiz M, Aladağ N, Topalli R, Ciğerli Ö, Görpelioğlu S. Counselling and knowledge about contraceptive mode of action among married women; a crosssectional study. BMC Womens Health. 2006;6:1-6.

7. Kim YM, Kols A, Martin A, Silva D, Rinehart W, Prammawat $S$, et al. Promoting informed choice: Evaluating a decisionmaking tool for family planning clients and providers in Mexico. Int Fam Plan Perspect. 2005;31(4):162-71.

8. Badan Kependudukan dan Keluarga Berencana Nasional. Batasan dan Pengertian MDK [Internet]. [cited 2020 Sep 23]. Available from:

http://aplikasi.bkkbn.go.id/mdk/ BatasanMDK.aspx

9. Widiastuti NM, Nopiyani NMS, Karmaya INM. Perbedaan Kepuasan Pasien Jaminan Kesehatan Nasional pada Empat Jenis Fasilitas Kesehatan Tingkat Pertama. Public Heal Prev Med Arch. 2015;3(2):119.

10. Wiknjosastro. IImu Kebidanan. 4th ed. Jakarta: Yayasan Bina Pustaka Sarwono Prawirohardjo; 2011.

11. Dyah Pratiwi E, Sariyati S. Agama dengan Keikutsertaan Keluarga Berencana (KB) dan Pemilihan Jenis Alat Kontrasepsi pada Pasangan Usia Subur (PUS) di Desa Argomulyo Sedayu Bantul Yogyakarta. J Ners dan Kebidanan Indones. 2016;3(1):1.

12. Indonesia U, Fienalia RA, Masyarakat FK, Studi P, Reproduksi K. Faktor-Faktor Yang Berhubungan Dengan Penggunaan Metode Kontrasepsi Jangka Panjang ( Mkjp ) Di Wilayah Kerja Puskesmas Pancoran Mas Kota Depok Tahun 2011 Faktor-Faktor Yang Berhubungan Dengan Penggunaan Metode Kontrasepsi Jangka Panjang ( Mkjp ) Di Wilaya. 2012; 
13. Wulandari FI. Hubungan Tingkat Pendapatan Keluarga dengan Pemilihan Alat KOntrasepsi Suntik. Infokes. 2013;3(3):14-24.

14. Harni AJ, Anita A. Perbedaan Lama Waktu Kembali Hamil pada KB Suntik 1 Bulan dengan KB Suntik 3 Bulan di Wilayah Kerja Puskesmas Daya Murni Kabupaten Tulang Bawang Barat Lampung. J Kesehat. 2017;8(3):429.

15. Rokom. Mengupas Kebijakan Jaminan Persalinan [Internet]. 2011 [cited 2020 Sep 22]. Available from: http://sehatnegeriku. kemkes.go.id/baca/blog/20110518/311069/ mengupas - kebijakan - jaminan persalinan/\#: :text=Jaminan Persalinan adalah jaminan pembiayaan, dan pelayanan bayi baru lahir.

16. Pratiwi NL, Basuki H. Health Seeking Behavior dan Aksesabilitas Pelayanan Keluarga Berencana di Indonesia (Health Seeking Behavior and Family Planning Services Accessibility in Indonesia ). Bul Penelit Kesehat Kesehatn. 2014;17:45-53.

17. Becker D, Koenig MA, Mi Kim Y, Cardona K, Sonenstein FL. The Quality of Family Planning Services in the United States: Findings from a Literature Review. Perspect Sex Reprod Health. 2007;39(4):206-15.

18. Agha S, Do M. The quality of family planning services and client satisfaction in the public and private sectors in Kenya. Int J Qual Heal Care. 2009;21(2):87-96.

19. Hutchinson PL, Do M, Agha S. Measuring client satisfaction and the quality of family planning services: A comparative analysis of public and private health facilities in Tanzania, Kenya and Ghana. BMC Health Serv Res. 2011;11.
20. Triyanto L, Indriani D. Faktor yang Mempengaruhi Penggunaan Jenis Metode Kontrasepsi Jangka Panjang (MKJP) pada Wanita Menikah Usia Subur di Provinsi Jawa Timur. Indones J Public Heal. 2018;13(2) (April):244-55.

21. Nasution SL. Faktor-faktor yang mempengaruhi penggunaan MKJP di Enam Wilayah Indonesia. Jakarta; 2011.

22. Prata N, Bell S, Holston M, Gerdts C, Melkamu Y. Factors associated with choice of post-abortion contraception in Addis Ababa, Ethiopia. Afr J Reprod Health. 2011;15(3):51-7.

23. Menteri Kesehatan Repulik Indonesia. Peraturan Menteri Kesehatan Republik Indonesia Nomor 28 Tahun 2017 tentang Izin dan Penyelenggaraan Praktik Bidan [Internet]. Jakarta; 2017. Available from: http://www.ibi.or.id/media/PMK No. 28 ttg Izin dan Penyelenggaraan Praktik Bidan.pdf

24. Apreliasari H, Antoni A. Kepuasan Akseptor KB Terhadap Pelayanan KB di Klinik Bersalin Nelly Padangsidimpuan. J Kesehat IIm Indones. 2020;5(1):56-60.

25. Pratiwi AM. Relationship Between Postpartum Health Care With Contraceptive After Childbirth In Indonesia. J Ners dan Kebidanan Indones. 2019;6(3):13.

26. Aryani F. Peran Bidan dalam Konseling Awal Kontrasepsi Suntik DMPA. J Ners dan Kebidanan Indones. 2016;1(3):82.

27. Sariyati S, Mulyaningsih S, Hadi H. Kemandirian Keluarga Berencana (KB) pada Pasangan Usia Subur di Kota Yogyakarta. J Ners dan Kebidanan Indones. 2016;2(2):62. 